\title{
Nature Conservation in the Transvaal
}

\author{
By R. Bigalke
}

In this brief survey of conservation in the Transvaal outside the Kruger National Park, Dr Bigalke, formerly Director of the National Zoological Gardens in Pretoria and now the Information Officer of the Transvaal Nature Conservation Branch, discusses some of the provincial reserves and private farms, and the excellent research that is being done, much of it with a practical application.

WJHEN in 1910 the four Crown colonies-Cape Province, Natal, Transvaal and Orange Free State - united to become the Union, now the Republic of South Africa, fish and game preservation were left in the hands of the individual provinces; flora protection and predator control were added later. In the Transvaal this situation continues today, except that the Kruger National Park, covering 7340 square miles, has been put in charge of a National Parks Board of Trustees, created in 1926. For the more than 102,000 square miles outside the park the provincial administration is responsible.

The Transvaal still has more kinds of large animals than any of the other three provinces, although they have disappeared from many areas where they were once plentiful. Only the square-lipped (white) and black rhinos have disappeared altogether in the $\mathbf{1 3 0}$ years since the province was settled, and recently the square-lipped rhino has been brought back from the Umfolozi Game Reserve in Zululand. The calf born in the Loskop Dam Nature Reserve on April 11th, 1964 was an event of great importance, the first birth in the Transvaal since 1896, when the square-lipped rhino became extinct there. Another heifer calf was born at Loskop on July 6th, 1966. However, in the last decade there has been a remarkable revival of interest in wildlife, to be seen in the thousands who flock to the country's nature reserves every year, and also in the intense interest shown by farmers in restocking their land with at least some of the fine antelopes indigenous to South Africa. Private nature reserves are encouraged, and game animals are still abundant outside the Kruger in such places as the Timbavati and similar reserves, and the Sabi-Sand Wildtuin and other unfenced farms. The Timbavati private nature reserve comprises sixteen farms covering 238 square miles along the western border of the Kruger and south of Nhlalarumi River, with a six-foot fence inside which the game can move about freely. Landowners with game on their farms, and wanting the maximum protection offered by the Ordinance, apply for their land to be proclaimed a nature reserve. In May 1968 there were 408 of these private reserves covering some 3964 square miles, which is more than half the area of the Kruger Park.

The Nature Conservation Ordinances of January 1st, 1968, is administered by the Director of Nature Conservation, under whom are three senior nature conservation officers, 18 conservation officers and 38 rangers. 
Their incessant activity can be gauged from the fact that in one year, 1966, they travelled 438,726 miles, and brought 1696 successful cases to the courts, mostly offences against the game ordinance. Many firearms, cartridges, hunters' lamps, snares, traps, fish-traps and other equipment were confiscated, and prison sentences and fines totalling R89,304 imposed. Most of the cases against non-whites were for killing game by means of wire snares, a cruel method that will probably never be completely eliminated; in 1963 between 600 and 700 springtraps were confiscated.

Of the Transvaal's 17 provincial nature reserves, with a combined area of approximately 208 square miles, the most widely known is the 41-squaremile Loskop Dam Nature Reserve, now a popular holiday resort. Here various kinds of game animals have been re-introduced, including 12 square-lipped rhinos. Game has increased rapidly and can now been seen by tourists, and there are about 290 species of wild birds. The Lombard Nature Reserve near Bloemhof has been stocked with game species that formerly occurred there, from which it is hoped to supply farmers who want to stock their farms with high veld antelopes; already black wildebeest, impalas, blesbucks and springboks have been supplied. Fox-hounds are bred and trained for use in destroying jackals through the jackal clubs, and research is being done on game conservation and harmful predators. A detailed study of antelope hair has proved of practical value in the identification of biltong in poaching cases. The primary object of the Hans Merensky Nature Reserve, on the Letaba River in the Low Veld is to provide for species like roan, sable, tsessebe and nyala, all among the rarer kinds of South African antelope, some of which have still to be introduced into the reserve.

In the north the Percy Fyfe Nature Reserve, a gift to the province by the late Mr Percy Fyfe and his wife, has a large herd of blesbok, from which more than a thousand have been supplied to farmers and others. The Barberspan Nature Reserve, near Delareyville, is a waterfowl sanctuary with an abundance of flamingos, pelicans, waders and other aquatic birds. Nearly 230 bird species have been recorded, about one-fifth of them migrants, many of which have been ringed for migration studies. Barberspan is also a favourite anglers' resort. In 1965 the Nature Conservation Branch and the departments of Zoology and Microbiology in the University of Potchefstroom started a three-year programme of co-operative research on the physical, chemical and biological phenomena of Barberspan. This includes population studies of the different kinds of fish, and 75,188 fish have been netted, marked and liberated again. Collaboration with scientists from overseas included a study at the Barberspan Ornithological Station of certain problems of fight orientation in migratory birds by a specialist from the famous Max Planck Institute in Germany. These experiments were among the first of their kind in the southern hemisphere.

The Ida Doyer Nature Reserve in the mountains south-east of Barberton, a small reserve of only 37 morgen, was presented by $\mathrm{Mr}$ and Mrs $\mathrm{O}$. $\mathrm{T}$. Doyer to preserve a rare cycad tree, Encephalartos paucidentatus, which so far as is known, occurs only in this particular part of the Transvaal. The Blyderivierspoort Nature Reserve, in a scenically unexcelled part of 
the Transvaal Drakensberg Mountains south of Mariepskop, is to be developed as a multi-purpose area - a nature reserve in which all wild animals and wild plants are protected, but with recreational facilities as well.

Much is being done for the province's army of freshwater anglers. About 70,000 licensed anglers spend more than eight million rand per annum on their sport, and every year take more than 4500 tons of fish. The Transvaal now has no fewer than five research institutions, of which the largest - the Provincial Fisheries Institute in Lydenburg - concentrates on freshwater fish research in the interests of angling. The work there has led to the re-classification of the yellow fish group of Transvaal freshwater fishes by $\mathrm{Mr} \mathrm{A}$. Groenewald, who was also responsible for an important break-through in our knowledge of the breeding of the small-mouthed yellow fish Barbus holubi. Attempts to breed B. holubi at Lydenburg, begun in 1950, made little progress because the fish's eggs could not be found in the rivers. After a ten-year search, on Christmas Day 1960, Mr Groenewald succeeded in finding them. It was then discovered that their failure to breed had been due to inadequate circulation of water through the nest material, so that the eggs died from lack of oxygen, an important discovery in view of the angling pressure on our inland waters. The Lydenburg biologists were now able to replenish the populations of $B$. holubi, and the first consignment of 6000 fingerlings was liberated in Rietspruit at Loch Vaal, on August 6th, 1963. Since then nine dams, one in Rhodesia, and a part of the Crocodile River near Nelspruit have been stocked with 57,790 fingerlings, all bred at Lydenburg - a good example of the practical value of biological research. The Low Veld Fisheries Research Station near Marble Hall was established mainly for research on fish farming, with the object of introducing more proteins into the African diet, fish being a cheap substitute for meat.

The phenomenal development of industry in recent years has brought difficult problems. More factories means increased danger of water pollution in rivers, lakes and dams, which destroys fish and other aquatic animals, and also vegetation, so that the waters become sterile, while water for human consumption may become so polluted that it can only be purified at great cost. This problem is so important that the Director of Nature Conservation has been provided with a laboratory in Pretoria where the hybrobiological and chemical composition of standing waters in the Transvaal are being studied as well as the resistance of fish to pollution.

When the bilharzia problem became serious in Transvaal some years ago, attempts were made to control the intermediate hosts, the snails, with copper sulphate, which could also destroy fish and other aquatic life. Following protests by the Director of Nature Conservation, the Transvaal Provincial Council offered R4,000.00 a year for research; with this the Council for Scientific and Industrial Research established a bilharzia research unit, and copper sulphate was found to be an unsatisfactory remedy against snails. 


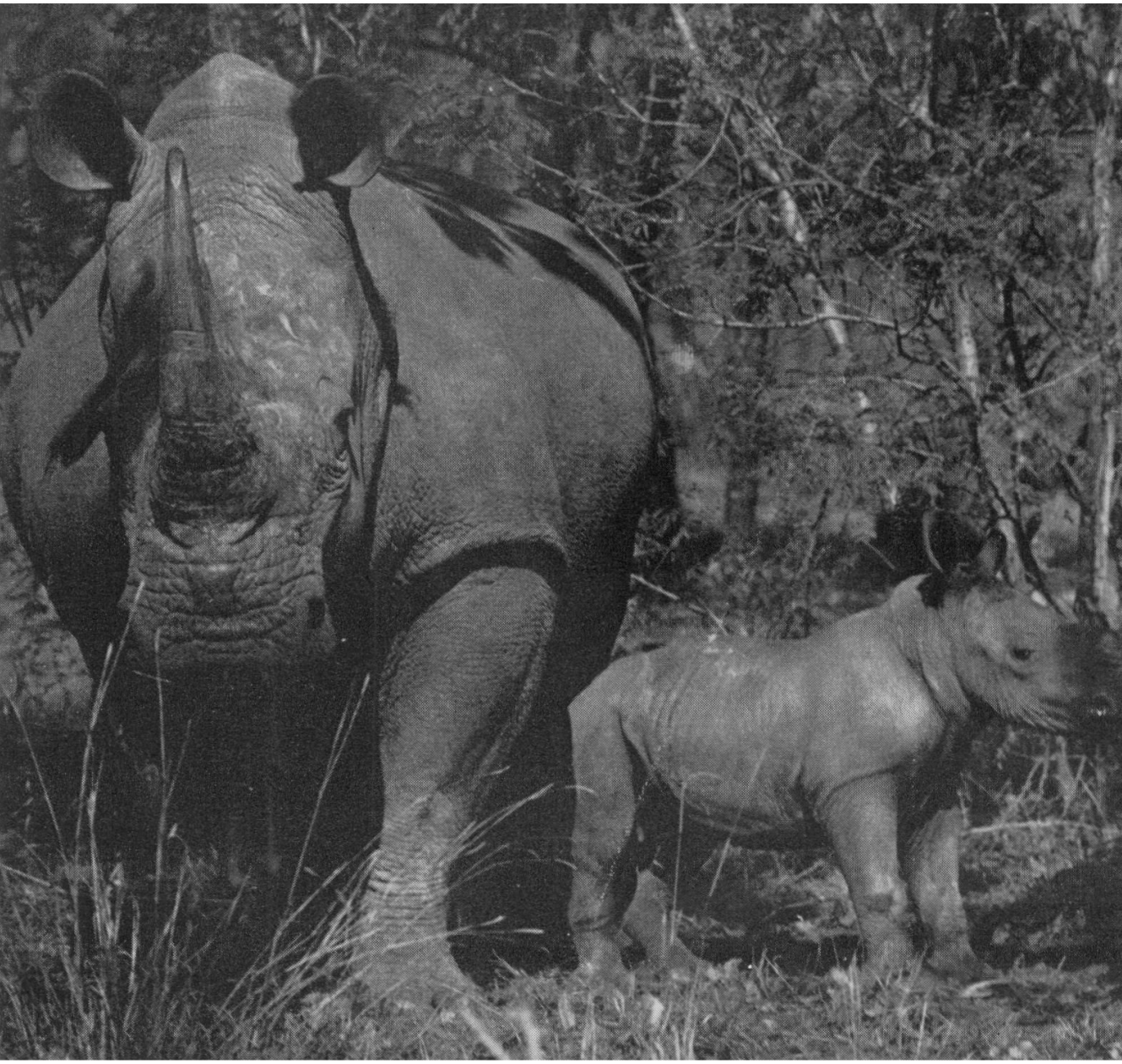

WHITE RHINO WITH HER CALF, the second to be born in the Loskop Dam Nature Reserve in the Transvaal. Ten white rhinos have been taken to Loskop from Umfolozi Game Reserve in Zululand, where they became too numerous.

Operation Rhino has now moved 482 rhinos from Umfolozi to other reserves in Africa and to zoos all over the world. Dick Woolf 


\section{Going to
South Aspica}

... sea people have far more fun than jet people

If you're in haste, fly. If you aren't, sail Union-

Castle and give yourself a wonderful time eleven days cruising through sunshine and blue sea with best food, best wine, best service, best everything. Experienced travellers sail with us over and over again.

If you must fly one way we have the perfect answer-inclusive holidays and travel using special air/sea arrangements. Ask your travel agent for further details. There are no currency restrictions in South Africa or on Union-Castle ships.

\section{UMION-CASTLE}

19 Old Bond Street, London, W.1. (01-493 8400) 


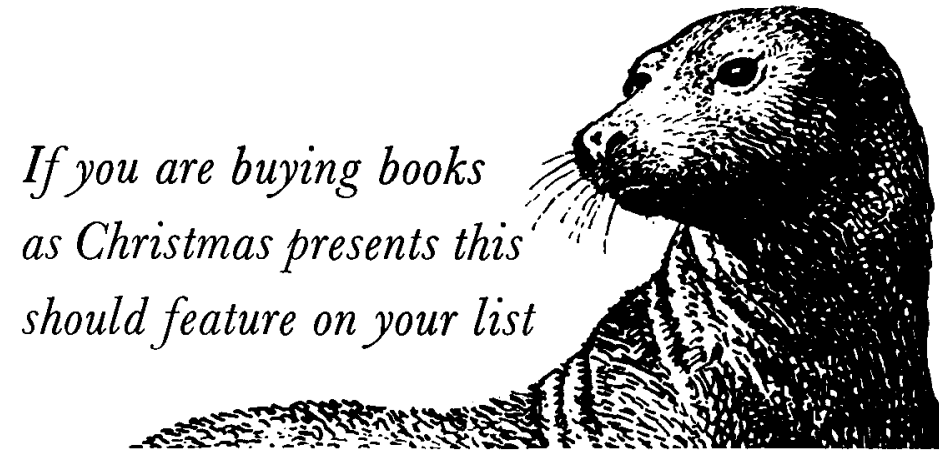

\section{VANISHING WILD ANIMALS} OF THE WORID

What is Man doing to the wild animals of the world? This handsome and authoritative volume deals with the 372 species which are in danger, shows where they live, why they are in peril and how they can be saved. 43 of them are depicted in full colour, and there are many line drawings and maps.

\section{Exceptionally low price}

Because of generous sponsorship by the Midland Bank, this beautiful and informative book can be offered at the extremely attractive price of $30 \mathrm{~s}$. All royalties are being given to the World Wildlife Fund, British National Appeal.

Text by Richard Fitter. Illustrations by John Leigh-Pemberton. With a Foreword by H.R.H. Prince Philip and Introduction by Peter Scott. $11 \frac{1}{2}$ in. $x 9$ in. 160 pp. approx. 43 colour plates. 29 drawings. 55 maps. Price 30 s. from any bookseller.

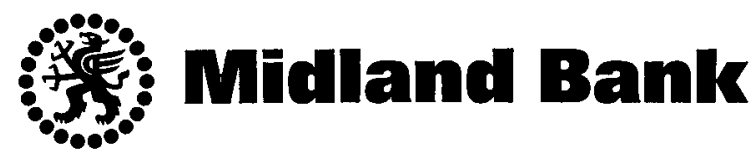




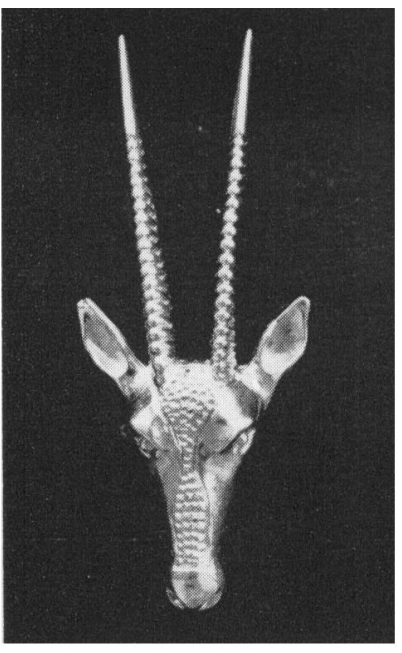

\section{SOME FPS GIFTS}

See opposite
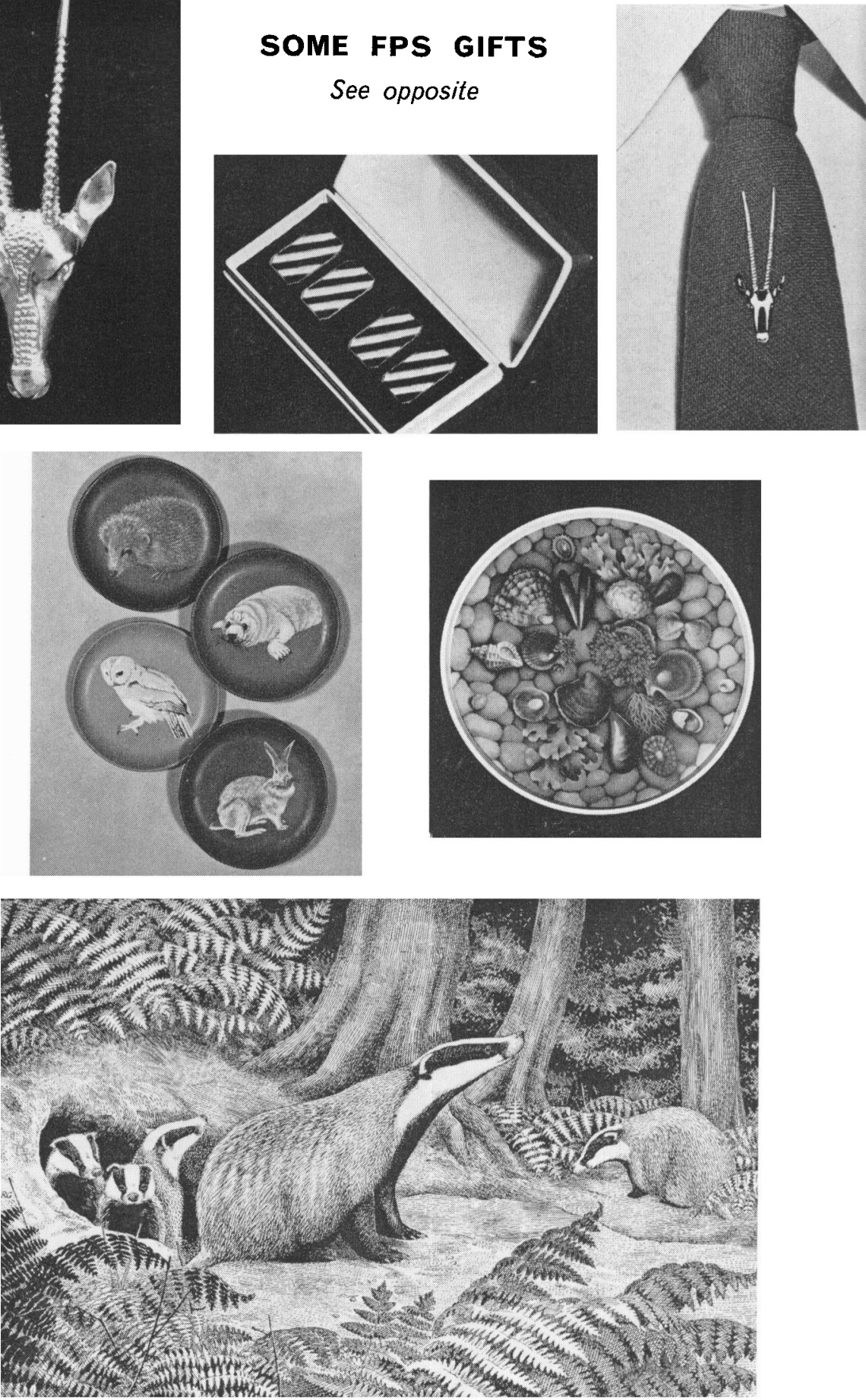


\section{FPS Gifts and Goods}

A selection of FPS gifts is illustrated opposite. An order form is enclosed with this issue of ORYX. (Extra forms gladly supplied). All sales benefit the Society.

Top row, left: Oryx Brooch, in gold or silver, $1 \frac{1}{2}$ " long, packed in a velvetlined box. Chased 9ct gold, £10; chased silver, hall-marked, £4 10s; plus 5s registered post, 10 s airmail.

Top row, centre: Zebra Cuff Links, in black and white enamel, hard gold plated, ${ }^{\prime \prime}$ deep, chain-linked, £3, post free.

Top row, right: FPS Tie, the new design, in Terylene, in mid-blue, crimson, olive green, silver grey, $£ 1$ (post 1s).

The old FPS tie, with all-over design of oryx heads, £1 (post 1s) navy blue, maroon and green.

Centre row, left: Scatter Dishes. Set of six (four illustrated) 4" Melamine dishes (2 beige, 2 light brown, 2 green), in a case, each with British mammal design, $£ 13 s$. Also, not lllustrated, similar set of six dishes in white with British mammal design in black and green, $£ 13 s$.

Centre row, right: Tray, in Melamine; heat, stain and spirit-proof; seashore design in greys, pinks, mauve and sand colours; 13", 29s 11d.

A/so available, not illustrated,

Matching Stand: the same design in a $6 \frac{1}{2}$ "stand for teapot, etc. $12 \mathrm{~s} 6 d$.

Matching Set - tray and stand-seashore design, 39s 11d. Both stand and tray are also available in two other designs: 'Humming Birds among Flowers' and 'British Butterflies', both in colour. Tray, 26s 11d; Stand, 12s 6d; Matching Set $37 \mathrm{~s} 11 d$. All Melamine goods are post paid.

All Melamine goods are available by courtesy of the World Wildlife Fund.

Bottom: Badger Print, by Robert Gillmor, in limited edition of 200, each signed by the artist and numbered. Overall size, 14" $\times 16 z^{\prime \prime}$ (drawing $7 t^{\prime \prime} \times$ $\left.10 z^{\prime \prime}\right)$. Packed, rolled ready for framing, 2 guineas, post free. With print mounted, protectively treated, framed in black and ready to hang, $£ 317 \mathrm{~s} 6 d$, post free.

Not illustrated:

Irish Linen Tea Towel, British mammals in colour on green ground $6 s 6 d$. White Ball-point Pens, gilt engraved 'Fauna Preservation Society', $1 s$.

\section{Books and Reports}

The FPS can supply the following books and reports:

Vanishing Wild Animals of the World by Richard Fitter, illustrated by John Leigh Pemberton, 30s. (Please state if you would like a copy signed by the author.)

The Animal Anthology by Diana Spearman, 25s; paperback, 8s $6 d$.

Bird Guide of Thailand by $\mathrm{Dr}$ Boonsong Lekagul, $£ 32 s 6 d$.

Predatory Mammals in Britain, 5 s.

A Hundred Years of Modern Whaling by E. J. Slijper, free.

Red Data Book of Endangered Species (IUCN): 2 vols, Mammals and Birds, in box, $£ 8$; Single volumes, $£ 4$.

First Seven Years of the Charles Darwin Foundation for the Galapagos Islands by Jean Dorst and Jacques Laruelle, $£ 1$.

Conference on Conditions of Transport and Importation of Live Birds, ICBP, 6s.

Management Policy in the National Parks of Tanzania by Professor E. Walter Russell 5s, post $6 d$.

Postage and packing extra - see order form enclosed. 
continued from page 428

Research on the Transvaal's flora consists chiefly of the distribution and ecology of rare and economically important indigenous plants with a view to their conservation. The botanist also works in collaboration with the ecologists who are busy with the study of the food habits of game, and a plant-ecological survey of the Hans Merensky Nature Reserve is being undertaken in relation to the grazing requirements of game. In 1965, thanks largely to the efforts of Transvaal's Director of Nature Conservation, Mr T. J. Steyn, a postgraduate course in wildlife management was started at the University of Pretoria, a one year BSc Honours course based on a previous degree in biology, which can lead to an MSc or a doctor's degree. Funds for this were obtained from private sources under the aegis of the Wild Life Protection and Conservation Society. This is undoubtedly the most important development for nature conservation in the Republic since the passing of the National Parks Act.

Between them the Provinces have 41 scientists working in their conservation services, of whom 17 are in the Transvaal. In Natal there are nine biologists and other scientists in the conservation service, and in the Cape Province 12 in addition to the scientific director. These men are setting the pace for scientific nature conservation in Africa.

\section{New Reserve in Tchad}

A gift of 100,000 Swiss francs from WWF has enabled the Tchad National Parks to buy a light aeroplane which has not only made it possible to enforce poacher control in the Zakouma and Manda National Parks and in the six existing game reserves, but has also made possible the declaration of a new reserve in the northern desert for addax and scimitar-horned oryx.

Kingfisher

\section{¿. . a news service of unequalled}

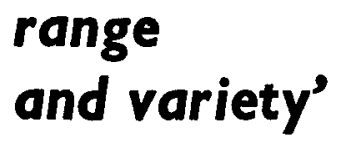

The only newsletter in the world devoted entirely to news and views about wildlife throughout the world, and the problem of its conservation. KINGFISHER, founded in 1965, is now read in more than $\mathbf{4 0}$ different countries in all five continents.

KINGFISHER is edited by Richard Fitter, Hon Secretary of the Fauna Preservation Society, and a member of the Survival Service Commission of the International Union for Conservation of Nature. His contacts throughout the world enable him to give readers of KINGFISHER a news service of unequalled range and variety.

Annual subscription: $£ 1$ ( $\$ 2.60)$ or by Airmail $f 110 s(\$ 3.85)$ for six issues a year. Send order to RINGFISHER, 6 Gombards, St Albans, England.

Specimen copy sent on request. 